\title{
PRAWNIK JAKO PEACEMAKER \\ - PRZEPROSINY, PRZEBACZENIE, POJEDNANIE W OPANOWYWANIU SPORÓW PRAWNYCH
}

\section{WPROWADZENIE}

Celem artykułu jest przybliżenie specyficznej roli zawodowej lub społecznej, określanej mianem lawyer as peacemaker ${ }^{1}$, jaka może przyjmować prawnik świadczący pomoc, zwłaszcza na rzecz klienta będącego strona sporu prawnego ${ }^{2}$. Wydaje się ona wciąż niedostatecznie doceniana zarówno przez polska naukę, edukację, jak i praktykę prawnicza. Tymczasem stałe poszukiwanie, badanie i aplikowanie różnorodnych, polubownych form opanowywania sporów prawnych (w tym wykorzystujacych takie instytucje, jak: przeprosiny, przebaczenie i pojednanie), prowadzacych do realnego likwidowania nie tylko negatywnych skutków konfliktów, lecz także ich przyczyn - należy uznać za jak najbardziej zasadne. Poza aspektem poznawczym takie podejście może bowiem przynieść różnorodne korzyści prawne i pozaprawne w wymiarze indywidualnym, interpersonalnym i społecznym ${ }^{3}$. Niemniej prawnicy nadal znacznie częściej sytuowani są po stronie zawodów, w które wpisane są raczej konfrontacja, rywalizacja i walka aniżeli zrozumienie, współpraca, porozumie-

${ }^{1}$ Znalezienie polskiego terminu, którym można by w podjętym kontekście rozważań adekwatnie zastapić anglojęzyczne określenie lawyer as peacemaker, nie jest zadaniem łatwym. Niemniej autor zgłasza propozycję rozważenia (zwłaszcza przez przedstawicieli nauki prawa) odpowiedniości posługiwania się polskimi określeniami „prawnik jako twórca i strażnik pokoju” bądź „prawnik jako promotor pokoju”, które wydają się najbliższe przedstawionemu w tekście rozumieniu analizowanej roli prawnika.

${ }^{2}$ Rola prawnika jako peacemakera jest możliwa do wykonywania przede wszystkim w ramach zawodu adwokata, radcy prawnego, negocjatora lub mediatora. W pewnym zakresie może być również realizowana przez sędziego, zwłaszcza nowatorskiego rodzaju sądu, określanego mianem problem-solving court. W ramach interdyscyplinarnej instytucji Problem-Solving Court sędzia, przyjmując tzw. holistic approach to justice (adaptujący odpowiednio założenia sprawiedliwości proceduralnej oraz therapeutic jurisprudence), może bowiem poza tradycyjna rolą funkcjonować również jako specyficzny tzw. therapeutic agent, behavior change agent, social worker, preacemaker czy motivator - zob. Winick (2013): 211-212, 217-228, 231-232. Na temat ról zawodowych i szerszej kategorii ról społecznych w kontekście zawodu prawnika - zob. np. Kaczmarek (2014); Łojko (2005); Skapska, Czapska, Kozłowska (1989). Por. Bieliński (2013): 25-34. Na temat roli prawnika jako peacemakera - zob. np. Wright (2010). Na temat specyficznych ról, które może realizować tzw. holistyczny prawnik - zob. Zienkiewicz (2018): 177-247.

${ }^{3}$ Pojęcie opanowywania sporów (w tym ich rozstrzygania albo rozwiązywania) w polskiej teorii prawa zdefiniował i rozpowszechnił Korybski (1993): 8, 193. Na temat tzw. holistycznego opanowywania sporów - zob. Zienkiewicz (2018): 248-275. Por. Daicoff (2013): 131-180. 
nie czy pojednanie stron konfliktów ${ }^{4}$. Dzieje się tak, mimo że tradycyjny proces sądowy w sytuacji występowania, zwłaszcza istotnych, problemów psychologicznych, relacyjnych czy społeczno-bytowych stron nie daje żadnej pewności na trwałą likwidację przyczyn ich problemów i sporów, ustanowienie pokojowych relacji interpersonalnych czy pozytywną przemianę osobowa, gwarantująca brak powrotu do negatywnych postaw i zachowań naruszajacych prawo lub inne normy społeczne ${ }^{5}$. Z drugiej natomiast strony zjawisku prawa można przypisać co najmniej dualistyczną naturę, łączącą przymus i dyskurs, w tym negocjacyjny, który może przyjmować formułę konfrontacyjną, ale również integracyjna, zmierzajaca do rozwiązania problemu bądź sporu prawnego na drodze porozumienia, dającego szansę na poprawę komunikacji i relacji stron oraz ich konstruktywną współpracę w przyszłości ${ }^{6}$.

Podjęte rozważania skoncentrują się na zaprezentowaniu przyjmowanego przez autora rozumienia i celów specyficznej roli prawnika jako peacemakera, podejmującego się adekwatnie do danego konfliktu interpersonalnego bądź grupowego funkcji promotora, strażnika, a nawet twórcy pokoju społecznego. peacemaker. Następnie przedstawione zostana podstawowe kwestie dotyczace instytucji przeprosin, przebaczenia i pojednania stron konfliktu, które sa szczególnie doniosłe dla praktyki opanowywania sporów prawnych, opartej na tzw. peacemaking. W toku analizy zidentyfikowane zostana ponadto wybrane regulacje polskiego materialnego prawa cywilnego i karnego odwołujące się do przeprosin, przebaczenia lub pojednania. Obecność tychże regulacji w systemie prawa polskiego - nawet w sytuacji niechęci niektórych prawników do polubownego opanowywania konfliktów - powinna skłaniać do bliższego poznania ich istoty (i to nie tylko w kontekście normatywnym) oraz do odpowiedniego uwzględniania w praktyce doradczej, a także sądowego rozstrzygania sporów w relewantnych okolicznościach faktycznoprawnych danej sprawy.

\section{PRAWNIK JAKO PEACEMAKER}

Prawnik przyjmujący rolę tzw. peacemaker koncentruje się przede wszystkim na skutecznym zapobieganiu zjawiskom powstawania, odnawiania się i eskalowania konfliktów oraz realnym i trwałym rozwiązywaniu problemów i sporów prawnych, opierając się na tzw. peacemaking ${ }^{7}$, które uwzględnia różne aspekty życia człowieka, wykorzystując również dorobek nauk pozaprawnych (zwłaszcza psychologii i socjologii) oraz współpracę prawników z ekspertami z innych dziedzin w ramach tzw. collaborative team (np. terapeutami,

\footnotetext{
${ }^{4}$ Zienkiewicz (2018): 13.

${ }^{5}$ Zienkiewicz (2018): 13. Podobnie podkreślają Płeszka et al. (2017): 96; Rękas (2011): 18.

${ }^{6} \mathrm{Na}$ temat dualistycznej natury prawa $\mathrm{z}$ charakterystyką społecznych funkcji pełnionych przez prawo: zarządzania (governance), podziału (distribution) oraz opanowywania sporów (dispute settlement and managment) - zob. Korybski (1993): 48-49. Na temat dyskurs integracyjnego - zob. Zienkiewicz (2014): 189-198.

${ }^{7}$ Szerzej zob. Noll. Por. Wright (2010); Carter (2010).
} 
lekarzami, mediatorami czy pracownikami socjalnymi) ${ }^{8}$. Peacemaking bazuje na pozytywnym rozumieniu terminu „pokój” (tzw. positive peace), postulującym w sytuacji konfliktu jego przezwyciężenie przez odpowiednią współpracę stron, zmierzającą do zawarcia porozumienia, które w miarę możliwości i potrzeb danej sprawy może poprzedzić ich wzajemne zrozumienie, przeproszenie, wybaczenie oraz pojednanie. Od pokoju w ujęciu pozytywnym odróżnia się tzw. negative peace, polegający na doprowadzaniu jedynie do stanu neutralizacji negatywnej komunikacji stron sporu (pomimo nadal ich wrogiego nastawienia) oraz zaprzestania przez nie aktów przemocy lub innego negatywnego zachowania. Przy czym zazwyczaj udaje się go osiagnąć przez przymus, wzajemne uzależnienie, ograniczenia, kontrolę bądź władczą interwencję podmiotów trzecich posiadajaccych uprawnienie do nakładania sankcji ${ }^{9}$. Istota pokoju $\mathrm{w}$ wymiarze pozytywnym jest natomiast spowodowanie likwidacji przyczyn konfliktu, odbudowanie przyjaznych relacji i podstaw współpracy stron sporu na przyszłość, a także ich trwała pozytywna przemiana behawioralna i personalna (w tym moralna). Positive peace osiagany jest głównie przez zastosowanie różnych form polubownego opanowywania sporów, bazujących na paradygmacie win-win solution, z odpowiednim uwzględnieniem interesów otoczenia społecznego oraz heteronomicznych bądź autonomicznych źródeł i formuł sprawiedliwości. Prawnik jako peacemaker znacznie częściej podejmuje się zatem doradztwa lub reprezentacji klienta w ramach mediacji, negocjacji integracyjnych czy collaborative law, stroniąc od antagonizujacej roli zastępcy procesowego $\mathrm{w}$ postępowaniu sądowym ${ }^{10}$. W analizowanym podejściu proces sądowy traktowany jest bowiem jako ostateczność, gdyż orzeczenie sądowe chociaż rozstrzyga spór, realizując ustanowione przez prawodawcę normy prawa materialnego i procesowego, niejednokrotnie nie powoduje jednak realnego ani trwałego rozwiąania konfliktu stron i prowadzi nawet do jego eskalacji ${ }^{11}$.

Przywrócenie tzw. pozytywnego pokoju między skonfliktowanymi stronami jest niejednokrotnie zadaniem bardzo trudnym, wymagajacym szerszego spojrzenia na zjawisko konfliktu i cele opanowywania sporów prawnych w wymiarze personalnym, interpersonalnym i społecznym. Prawnik jako peacemaker buduje podejście do prawa, własnych zadań i kompetencji na fundamentalnym założeniu, że zwłaszcza „prawo w działaniu” ma potencjał pozytywnej indywidualnej i interpersonalnej zmiany sytuacji i samych podmiotów oraz oferowania takich rozwiązań spraw prawnych, które daja stronom także szanse na bardziej satysfakcjonujące, harmonijne funkcjonowanie

${ }^{8}$ Szerzej na temat współpracy prawnika z collaborative team w ramach różnych typów spraw i gałęzi prawa - zob. np. Gutterman (2004): 97-244, 435-443.

9 Por. Noll. Przyjmowane założenie o celowości wprowadzania pokoju w stosunkach międzyludzkich jest zgodne z moralnością chrześcijańską - zob. np. tzw. Kazanie na Górze Jezusa, wymieniające osiem powiązanych ze sobą błogosławieństw, w tym co do osób wprowadzających pokój między ludźmi - zob. Ewangelia św. Mateusza (Mt 5, 1-12). Szerzej zob. Augustyn (2001); Martini (2008).

10 Szerzej na temat collaborative law - zob. np. Tesler (2008).

11 Por. Noll. 
indywidualne i społeczne (m.in. na opanowanie różnorodnych przyczyn natury behawioralnej, psychologicznej czy społecznej, powodujących problemy wspomnianych podmiotów z prawem lub członkami społeczności, w których na co dzień żyją ${ }^{12}$ ). Konsekwencją takiego ujęcia jest uwzględnianie przez prawnika - peacemakera w praktyce prawniczej nie tylko potrzeb i interesów klientów czy stron sporów o charakterze prawno-ekonomicznym (tzw. legal needs), lecz także potrzeb w szerszym humanistycznym wymiarze (tzw. human needs). Wpływa to na poszukiwanie przez niego optymalnych rozwiąań danego prawnego problemu czy sprawy z uwzględnieniem również jej pozaprawnych wymiarów o charakterze psychologicznym, emocjonalnym, komunikacyjnym, relacyjnym bądź etycznym (m.in. w celu określenia ich oddziaływania na stan psychofizyczny człowieka). Takie podejście do praktyki prawniczej dostrzega poza tradycyjnymi funkcjami prawa również jego terapeutyczny/ antyterapeutyczny i transformatywny potencjał wpływu na sfery behawioralna, psychiczną czy społeczną życia człowieka ${ }^{13}$. Podczas rozwiązywania problemów prawnych, a zwłaszcza opanowywania sporów, istotne znaczenie moga bowiem mieć nie tylko kwestie regulowane przez tradycyjny kontekst prawno-ekonomiczny (oparty na podejściu rywalizacyjnym, ustalajacym stopień zawinienia stron bądź to, która $\mathrm{z}$ nich ma rację), ale również kategorie osobowe, takie jak np.: zrozumienie, przeproszenie, przebaczenie, pojednanie, uzdrawianie relacji i postaw oraz budowanie harmonii osobistej, interpersonalnej i społecznej. Przyjmowane rozumienie roli prawnika jako peacemakera stoi zatem w opozycji do traktowania przymusu jako jedynie pożądanej czy zawsze dominującej cechy porządku prawnego - stanowi alternatywę dla wyłącznie procesowego, rywalizacyjnego realizowania profesji prawniczej. Prawnik jako peacemaker przyjmuje holistyczną postawę w praktyce zawodowej, diagnozując i opanowując spór z uwzględnieniem jego aspektów prawnych i relewantnych wymiarów wykraczajacych poza sferę stricte prawną (która modelowo może przyjać postać tzw. holizmu właściwego albo transformatywnego), traktując konflikt jako jedynie element całokształtu sytuacji życiowej klienta/ stron sporu ${ }^{14}$.

Przyjmowane przez peacemaking wieloaspektowe cele i formy opanowywania sporów prawnych korespondują z alternatywnym i holistycznym podejściem do sądowego wymierzania sprawiedliwości, którego doskonała egzemplifikacje stanowią tzw. problem-solving courts (bazujace zwłaszcza na złożeniach orientacji therapeutic jurisprudence) ${ }^{15}$. Problem-solving courts stanowią wyspecjalizowana, interdyscyplinarną instytucję, skoncentrowana

12 Por. Daicoff (2011): 36.

${ }_{13} \mathrm{Na}$ temat terapeutycznego i transformatywnego wymiaru (funkcji) prawa - zob. Zienkiewicz (2018): 121-135.

14 Szerzej na temat trzech głównych rodzajów holistycznych postaw w praktyce prawniczej (holizmu elementarnego, właściwego i transformatywnego), holistycznej diagnozy i opanowywania sporów - zob. Zienkiewicz (2018): 139-176, 177-205, 248-275.

${ }_{15}$ Szerzej na temat problem-solving courts - zob. np. Berman, Feinblatt (2002); Winick, Wexler (2003); Wiener, Brank (2013). Na temat związków problem-solving courts z therapeutic jurisprudence - zob. np. B. Winnick (2003): 1055-1090. Na temat holistycznego podejścia do wymiaru sprawiedliwości - zob. Zienkiewicz (2018): 309-402. 
na określonej kategorii spraw relewantnych prawnie, związanych również np. z uzależnieniem od narkotyków, bezdomnościa, bezrobociem, przemocą domową czy zaburzeniami bądź chorobą psychiczną stron(y) procesu. W ramach szerszego podejścia do wymierzania sprawiedliwości przed problem-solving courts, z jednej strony podejmowane sa tradycyjne kwestie typu ustalenie i ukaranie osób winnych przestępstwa czy zobowiązanie ich do zadośćuczynienia na rzecz pokrzywdzonego, z drugiej zaś - oferowana jest pomoc w zdiagnozowaniu głównych przyczyn problemów czy sporów stron (w tym wchodzenia w konflikt z prawem), dotyczących ich psychicznej, rodzinnej, zawodowej czy innej osobowej lub społecznej sfery życia. Ponadto podejmowane sa działania wspierające w zakresie likwidacji psychospołecznych problemów stron, wykorzystujące interdyscyplinarne programy sądowe, oferujace m.in. pomoc w zakresie edukacji, leczenia, terapii czy aktywizacji zawodowej. Realizowane sa one zazwyczaj przy udziale zespołu różnych specjalistów, funkcjonujących pod przewodnictwem sędziego w ramach tzw. multi-disciplinary team, w którego skład mogą wchodzić np.: psycholog, psychiatra, pedagog, pracownik socjalny, mediator, policjant, pracodawca, terapeuta rodzinny, a nawet osoby bliskie stronie procesu ${ }^{16}$. Programy wdrażane przez problem-solving courts angażuja zarówno koncepcję pozytywnej transformacji człowieka, jak i bardziej holistycznej praktyki sądowej ${ }^{17}$.

Proponowane podejście do zadań prawnika jako peacemakera wychodzi naprzeciw dostrzeżonemu przez Andrzeja Korybskiego zagubieniu w procesie ewolucji sądu roli prawnika jako twórcy i strażnika dobra, słuszności i pokoju społecznego, a także funkcji współczesnego sądu (oczywistej jeszcze kilka wieków temu) sprowadzającej się do utrzymania ładu i pokoju społecznego (idea „sądu pokoju społecznego") ${ }^{18}$.

\section{PRZEPROSINY, PRZEBACZENIE, POJEDNANIE W OPANOWYWANIU SPORÓW}

W ramach opanowywania sporów prawnych opierającego się na peacemaking jako szczególnie istotne traktowane sa instytucje przeprosin, przebaczenia oraz pojednania stron, gdy sprawa ma charakter cywilny, gospodarczy, rodzinny bądź karny ${ }^{19}$. Doprowadzenie przez prawnika - peacemakera - w razie zaistnienia takiej potrzeby i realnych możliwości do przeproszenia, wybaczenia i pojednania się stron stanowi bowiem solidny fundament skutecznego, wieloaspektowego opanowania sporu, dającego szansę na trwałą likwidację jego przyczyn oraz poprawę relacji i współpracę stron, skutkująca ich pokojowym współistnieniem (positive peace). Ewentualne pojednanie może jednocześsnie ułatwić stronie poszkodowanej pogodzenie się z doznaną szkodą majątko-

\footnotetext{
16 Daicoff (2011): 241; King et al.(2009): 82.

17 King et al. (2009): 82-83.

18 Korybski (1993): 60-61, 184, 188-189, 192, 193.

19 Podobnie Daicoff (2011): 150.
} 
wą czy krzywdą i zmniejszyć jej obawy przed ich ponownym wyrządzeniem w przyszłości. Może ono ponadto przynieść satysfakcję z faktu przyznania się przez przepraszającego sprawcę do błędów, wyrażenia skruchy oraz zobowiązania się do zaprzestania negatywnych zachowań. Osobie wyrządzającej drugiej stronie jakieś zło może natomiast umożliwić zrozumienie źródeł i skutków własnych zachowań, spoczywającej na niej odpowiedzialności, rozmiaru spowodowanych cierpień, zmotywować do pozytywnej przemiany, a także zmniejszyć wyrzuty sumienia. Ma to odniesienie zwłaszcza do sytuacji wywołania u sprawcy tzw. reintegrative shame (or guilt), klasyfikującej popełniony wobec pokrzywdzonego czyn jako naganny, jednakże bez potępienia przy tym własnej osoby jako nieodwracalnie złej, w tym zdolnej do dokonania aktu przeprosin czy pojednania się. Może to wytworzyć u sprawcy silną chęć zadośćuczynienia oraz trwałej, pozytywnej przemiany behawioralnej i personalnej (w tym moralnej), w opozycji do charakterystycznego dla tzw. unhealthy shame (or guilt) radykalnego zaniżenia samooceny sprawcy, możliwej recydywy negatywnych zachowań czy alienacji społecznej ${ }^{20}$.

Mając na uwadze wymiar indywidualny, interpersonalny i społeczny sprawy oraz jej pełen horyzont czasowy (przeszłość, teraźniejszość, przyszłość), prawnik przyjmujący rolę peacemakera powinien rozważyć zasadność, warunki i możliwości doprowadzenia do rzeczywistego aktu przeprosin przez stronę konfliktu, która jest do tego predysponowana (np. będąc wyłącznie winna wyrządzenia szkody). W'sród cech szczerych i skutecznych przeprosin można wymienić:

a) przekazanie, najlepiej w bezpośrednim kontakcie osobistym, przez przepraszającego osobie przepraszanej wprost słowa „przepraszam”, z jednoczesnym odczuwaniem przez przepraszającego wyrzutów sumienia oraz wyrażeniem żalu i skruchy;

b) przyznanie się do winy, wyjaśnienie przyczyn przewinienia oraz przedstawienie prośby o wybaczenie;

c) posiadanie przez przepraszającego intencji (planu) niepowtarzania nigdy więcej negatywnych zachowań wobec przepraszanego, zwłaszcza takich, za które się przeprasza;

d) danie wyrazu świadomości rozmiaru szkód, które spowodowało negatywne zachowanie przepraszającego, i ich wpływu na różne aspekty życia osoby przepraszanej;

e) w sytuacji adekwatności dodatkowo przyjęcie pełnej odpowiedzialności za spowodowaną szkodę oraz zaoferowanie zadośćuczynienia ${ }^{21}$.

Jednoznaczna ocena charakteru prawnego aktu przeprosin nie zawsze jest łatwa i powinna być dokonywana a casu ad casum. Może on bowiem bazować jedynie na oświadczeniu woli lub stanowić zespół różnych czynności prawnych bądź do nich podobnych, np. gdy sprawca w ramach przeprosin przyznaje się do winy, poddaje się dobrowolnie odpowiedzialności karnej lub cywilnej, zobo-

20 Scheff (1998): 104-106.

${ }^{21}$ Daicoff (2011): 149. Na temat instytucji przeprosin szerzej zob. np. Cohen (1999): 1009-1069; Lazare (2005); Daicoff (2013): 131-180. 
wiązuje się do spełnienia (albo od razu spełnia) konkretnego zadośćuczynienia bądź zaprzestaje działań prowadzacych do naruszeń dóbr osobistych poszkodowanego ${ }^{22}$.

Do przebaczenia ze strony osoby przepraszanej dochodzi zazwyczaj dopiero w sytuacji ocenienia dokonanych przez nią przeprosin jako szczerych i ich przyjęcia (zaakceptowania) jako formy zadośćuczynienia symbolicznego (czasami przy jednoczesnej pewności poniesienia przez sprawcę bardziej wymiernej, ekonomiczno-prawnej odpowiedzialności). Nie wyklucza to jednak możliwości wybaczenia przez poszkodowanego sprawcy, który nie dokonał w ogóle aktu przeprosin (np. motywowanej normami chrześcijańskiej moralności religijnej, miłosierdziem czy wielkodusznościa). Przez przebaczenie można rozumieć, zazwyczaj dobrowolny ${ }^{23}$, akt woli osoby pokrzywdzonej (poszkodowanej), który nie musi, ale powinien zostać przejawiony na zewnątrz w dowolnej formie (także per facta concludentia), dostrzegalnej dla otoczenia, jeżeli ma wywołać określone skutki prawne bądź społeczne ${ }^{24}$. Przy czym przebaczenie dla swojej skuteczności nie wymaga po stronie przebaczającego świadomości skutków prawnych z nim związanych ani zamiaru ich wywołania ${ }^{25}$. Jego istota polega na potraktowaniu wyrządzonej szkody (krzywdy) jako niebyłej, wyrzeczeniu się uczucia gniewu, urazy czy chęci zemsty wobec sprawcy. A ponadto na zrezygnowaniu przez poszkodowanego z powracania do przykrego zdarzenia i wywodzenia z niego skutków, w tym co do pociągnięcia sprawcy negatywnego zachowania do odpowiedzialności, która jest normatywnie uzasadniona (odrzucenie sankcjonowania w wymiarze prawnym lub moralnym) ${ }^{26}$.

Akt przebaczenia nie stanowi typowego oświadczenia woli ani czynności prawnej. W literaturze prawniczej określany bywa jako decyzja, akt czy też przejaw woli zbliżony do oświadczenia woli lub podobny do czynności prawnej ${ }^{27}$. Niektórzy autorzy podkreślaja, że jest to przede wszystkim wolitywny akt moralny ${ }^{28}$, inni - że to przejaw uczuć, a nie woli, co bywa słusznie

${ }^{22}$ Szerzej na temat czynności podobnych do czynności prawnych - zob. Mularski (2011).

${ }^{23}$ Akt przebaczenia jest co do zasady dokonywany dobrowolnie, w ramach wolności osoby przebaczającej. Polski system prawny nie zawiera norm nakazujących dokonywanie aktów przebaczenia przez osoby posiadające status pokrzywdzonego przestępstwem czy poszkodowanego deliktem cywilnym lub przez nierzetelnego kontrahenta umowy cywilnoprawnej. Są one jednak spotykane w obszarze moralności religijnej, np. w chrześcijaństwie nakaz przebaczenia został sformułowany przez Jezusa Chrystusa w odpowiedzi na pytanie ucznia: „Panie, ile razy mam przebaczyć, jeśli mój brat wykroczy przeciwko mnie?”. Następujące słowa Chrystusa: „Nie mówię ci, że aż siedem razy, lecz aż siedemdziesiąt siedem razy” można zinterpretować jako wezwanie czy przykazanie: „Masz przebaczać” - zob. Ewangelia św. Mateusza (Mt 18, 21-22), por. przykazanie miłości bliźniego (Mt 22, 34-40) (tłum za: Pismo Święte Nowego Testamentu i Psalmy. Biblia Tysiąclecia, wyd. 10, Poznań 2004: 42, 48-49). Pomimo jednak sformułowanego ewangelicznego nakazu, człowiek w ramach wolnej woli ostatecznie podejmuje decyzję o tym, czy dokonana aktu przebaczenia.

${ }^{24}$ Skowrońska-Bocian (2017a): teza 5; Trzaskowski (2017): teza 4; Księżak (2006): 57-58, 61.

${ }_{25}$ Skowrońska-Bocian (2017a): teza 2.

${ }^{26}$ Por. Księżak (2006): 57-58; Witko (2012).

${ }^{27}$ Trzaskowski (2017): teza 2. Szerzej zob. Mularski (2011): 230-234; Wilejczyk (2013): $101-111$.

${ }^{28}$ Ciszewski (2014): teza 9; Trzaskowski (2017): teza 3; por. Książek (2006): 58. 
uzupełnianie twierdzeniem, iż niejednokrotnie bywa on również przejawem rozumu ${ }^{29}$.

Przebaczenie powinno być co do zasady dokonywane osobiście przez poszkodowanego ${ }^{30}, \mathrm{z}$ tzw. dostatecznym rozeznaniem wszystkich istotnych okoliczności sprawy. Niedookreślone sformułowanie „dostateczne rozeznanie”, obecne w regulacjach polskiego prawa cywilnego, doktryna prawa charakteryzuje jako sytuację, w której osoba poszkodowana zdaje sobie sprawę z popełnienia przez sprawcę czynu nagannego, jest zdolna do rozumienia i odczuwania krzywdy, a także chce ja puścić w niepamięć, znając sens aktu przebaczenia oraz istotne okoliczności danego przypadku ${ }^{31}$. Uzależnienie skuteczności przebaczenia od dostatecznego rozeznania, a nie od pełnej zdolności do czynności prawnych, skutkuje tym, że w pewnych sytuacjach może ono zostać dokonane również przez osobę małoletnia, ubezwłasnowolnioną całkowicie albo częściowo bądź zaburzona albo chora psychicznie ${ }^{32}$.

Akt przebaczenia dla swojej skuteczności nie powinien być podejmowany pod wpływem istotnego błędu czy groźby ani pod warunkiem czy z zastrzeżeniem terminu ${ }^{33}$. Co do zasady ma charakter nieodwołalny ${ }^{34}$. Nie jest konieczne, aby przebaczenie było wyrażone w obecności osoby, która ma być jego beneficjentem, lub było wprost do niej skierowane ${ }^{35}$.

Ostatni akt $\mathrm{z}$ analizowanej triady, którym jest pojednanie, nie jest nigdy pewną czy oczywista konsekwencją dokonania nawet wzajemnego aktu przeprosin i przebaczenia, które niejednokrotnie stanowią jednak konieczne etapy dojścia do pojednania stron sporu ${ }^{36}$. Jest $\mathrm{w}$ pełni zależny od zbieżnej woli obydwu stron, determinowany całokształtem różnorodnych aspektów sprawy oraz wybranej formy i przebiegu postępowania w zakresie opanowania konfliktu. Akt pojednania wymaga odpowiedniej aktywizacji dotychczas skonfliktowanych stron, łączącej sferę wolitywna z jej przejawem, tj. kierunkowa czynnością dwustronną bądź kompleksem różnych czynności w dowolnej formie, które finalnie doprowadzą do osiagnięcia stanu pojednania. Podobnie jak przebaczenie może on stanowić pewien proces rozciagnięty w czasie. Nie może on jednak ograniczyć się jedynie do woli wewnętrznej, i to wyłącznie

${ }^{29}$ Ciszewski (2014): teza 9; por. Książek (2006): 54. Nie można również wykluczyć, że akt przebaczenia będzie wynikiem namysłu i merkantylnej kalkulacji przez pryzmat strata-zysk. Bez względu jednak na przypisywany mu status cywilnoprawny, bezspornie stanowi on istotne zachowanie w wymiarze nie tylko faktycznym bądź prawnym, ale często również w wymiarze etycznym, komunikacyjnym, relacyjnym, psychologicznym, religijnym bądź filozoficznym.

30 Niektórzy przedstawiciele doktryny prawa dopuszczają możliwość dokonania przez spadkobierce darczyńcy (we własnym imieniu) przebaczenia obdarowanemu jego niewdzięcznego zachowania, co miałoby skutkować wygaśnięciem uprawnienia do odwołania darowizny - zob. Karaszewski (2014): teza 2. Kwestia dokonywania przebaczenia w cudzym imieniu, zwłaszcza nieżyjących ofiar okrutnych zbrodni, budzi kontrowersje - por. Kołakowski (2007): 226-227; Saint-Cheron (2008): 184.

31 Skowrońska-Bocian (2017a): teza 4; Trzaskowski (2017): teza 3.

32 Skowrońska-Bocian (2017a): teza 4; Ciszewski (2014): teza 4.

${ }^{33}$ Trzaskowski (2017): teza 3; Ciszewski (2014): teza 4; Skowrońska-Bocian (2017b): teza 1.

${ }^{34}$ Księżak (2006): 64; Ciszewski (2014): teza 6. Przeciwnie - Stecki (2011): 356.

35 Karaszewski (2014): teza 6.

36 Por. Wilejczyk (2018): 283. 
jednej strony sporu. Z uwagi na to, że pojednanie jest wyjątkowo pomocne $\mathrm{w}$ odbudowaniu poprawnych relacji interpersonalnych, wzajemnego zaufania i daje stronom realną szansę na pozytywną i konstruktywną współpracę oraz pokojowe funkcjonowanie w przyszłości, powinno być szczególnie wspierane przez prawnika - peacemakera. Zwłaszcza w tzw. sporach osobowych, pomiędzy podmiotami w kontaktach długoterminowych, a także w takich, w których szczególnie pożądane są pozytywne więzi czy relacje (np. między członkami rodziny, małżonkami, sąsiadami, przedsiębiorcami czy pracownikiem i pracodawca). Dotyczy to w szczególności sytuacji, gdy negatywne skutki sporów odczuwalne są również dla bliższego bądź dalszego otoczenia społecznego stron.

Aktom przeprosin, przebaczenia czy pojednania moga towarzyszyć silne i przeciwstawne (pozytywne i negatywne) emocje, jednakże po ich dokonaniu zazwyczaj strony są w stanie poczuć ulgę czy osiagnąć wewnętrzny i interpersonalny pokój (tzw. harmonię horyzontalna, a w przypadku osób religijnych również harmonię wertykalną z Bogiem) ${ }^{37}$. Pozwala to na znacznie szybsze przepracowanie negatywnego nastawienia do sprawy czy przeciwnika w sporze i w efekcie ułatwia stronom i prawnikom postępowanie w kierunku polubownego i trwałego rozwiązania konfliktu.

Niemniej profesjonalny prawnik (funkcjonujaccy nawet w roli peacemakera), doradzając czy reprezentując klienta, pomimo zalet instytucji przeprosin, przebaczenia czy pojednania, powinien w każdej sprawie rozważyć, czy i jak warto inspirować strony sporu, by zdecydowały się pójść w tym kierunku. Winien on dokładnie oszacować wszystkie za i przeciw oraz ustalić optymalna alokację czasoprzestrzenną dla ich ewentualnego zaistnienia. W praktyce może bowiem się okazać, że z jakichś powodów klient nie życzy sobie być przeproszonym bądź że nie jest gotowy do złożenia szczerych przeprosin, czy też że dotkliwie odczuje odmowę przyjęcia aktu wybaczenia. Może się również zdarzyć tak, że dokonanie przez klienta przeprosin spowoduje znaczne osłabienie jego pozycji negocjacyjnej lub doprowadzi do przyjęcia przez sąd, że w sprawie doszło do uznania przez niego roszczenia lub przyznania się do winy i poddania się odpowiedzialności prawnej ${ }^{38}$.

Prawnik, zachęcajacy klienta do współdziałania w ramach postawy peacemaking, może spotkać się z jego obawa, że dokonane przeproszenie, przebaczenie lub pojednanie zniweczą szanse na odpowiednie wymierzenie sprawiedliwości np. niesolidnemu kontrahentowi, z którym zawarł on umowę, sprawcy deliktu cywilnego bądź przestępstwa, w efekcie doprowadzi więc do uniknięcia przez niego odpowiedzialności cywilnej lub karnej. Nie wchodząc w tym miejscu w szczegółowe analizy regulacji prawnych i orzecznictwa adekwatnych dla poszczególnych stanów faktycznych, należy generalnie przyznać, że rzeczone instytucje mogą mieć mniejszy bądź większy łagodzący wpływ na sądowy wymiar kary bądź cywilnoprawne obowiązki nakładane wyrokami sądów cywilnych, czy też na ustalane w ugodach pomiędzy stronami sporu. W niektórych

37 Daicoff (2011): 148.

38 Por. rozważania na temat tzw. „bezpiecznych” przeprosin (,safe” apology) - Cohen (1999): 1031-1042. 
przypadkach moga one jednak pozostawać zupełnie indyferentne względem odpowiedzialności prawno-ekonomicznej sprawcy, w szczególności wówczas, gdy nie sa ujawniane osobom trzecim, w tym sędziemu czy mediatorowi. Odczuwanie przez klienta/ stronę głębokiego rozziewu pomiędzy poczuciem sprawiedliwości czy słuszności a skutkami przeprosin, przebaczenia czy pojednania, które moga prowadzić w niektórych przypadkach nawet do uniknięcia przez sprawcę negatywnych czynów jakichkolwiek sankcji bądź konieczności naprawienia szkody - może stanowić istotną barierę dla ich realizacji podczas opanowywania sporów. Jej przezwyciężenie jest kwestią indywidualną i czasami może okazać się niewłaściwe lub niemożliwe, zwłaszcza gdy mamy do czynienia ze znacznym rozmiarem cierpienia po stronie poszkodowanego bądź jego najbliższych. Pomocne w ich osiagnięciu bywa uświadomienie stronom konfliktu fundamentalnych źródeł analizowanych aktów, którymi (w szczególności dla przebaczenia i pojednania) są miłość i miłosierdzie wobec drugiego człowieka, majace dla niektórych osób również istotny wymiar religijny ${ }^{39}$. Rozważając specyficzne relacje pomiędzy wskazaniami sprawiedliwości a miłościa czy miłosierdziem, stanowiącymi podstawę szczerego, często nieodwracalnego i bezinteresownego aktu przeprosin, przebaczenia czy pojednania skonfliktowanych stron, należy zauważyć, że nie muszą się one zawsze wykluczać czy stać do siebie w opozycji ${ }^{40}$. W ramach aktów miłosierdzia dostrzegana powinna być sprawiedliwość, nie są one jednak bezwzględnie związane jej nakazami, nie wyczerpują się w niej, ale niejako przewyższając jej wymogi, stanowią dar dla drugiej strony sporu, a czasami są wręcz przejawem heroicznej cnoty, jeśli uwzględnić rozmiary doznanych od niej krzywd ${ }^{41}$.

\section{REGULACJE POLSKIEGO PRAWA CYWILNEGO I KARNEGO ODWOLUJĄCE SIĘ DO PRZEPROSIN, PRZEBACZENIA I POJEDNANIA}

Analiza polskiego, materialnego prawa cywilnego i karnego prowadzi do wniosku, że przepisów, które odwołują się wprost do przeprosin, przebaczenia lub pojednania, jest niewiele. W odniesieniu do aktu przeprosin należy wskazać na art. $72 \S 1$ pkt 2 k.k., który stanowi, że zawieszając wykonanie kary, sąd zobowiąuje, a jeżeli orzeka środek karny, to może zobowiązać skazanego do prze-

39 Jak słusznie wskazuje Ciszewski (2014: teza 12) odnośnie do przebaczenia, jego istota jest humanitarny charakter i walor społeczno-etyczny. Por. Ochotny (2017): 87-101.

${ }^{40}$ Niejednokrotnie dochodzi bowiem zarówno do sankcjonowania negatywnych zachowań sprawcy czy jego zadośćuczynienia oraz aktu przeprosin, przebaczenia i pojednania się stron konfliktu. Bywa, że dopiero ich współwystępowanie zwiększa szansę na pozytywną przemianę behawioralną i personalną sprawcy, w tym na jego wzrost moralny.

41 Ochotny (2017): 93, 97-99. W tym miejscu należy zwrócić uwagę na podejmowane w literaturze filozoficznej i pedagogicznej istotne kwestie dotyczące napięcia między tzw. niewybaczalnym a radykalnym przebaczeniem wszystkiego, wymogiem skruchy a wybaczeniem bezwarunkowym, społecznym pojednaniem a indywidualnym, rozważane również w kontekście mechanizmów transformacji osobowości człowieka - zob. Maliszewski (2016): 11-24 i wskazana tam literatura. 
proszenia pokrzywdzonego ${ }^{42}$. W zakresie prawa cywilnego istotną regulację zawiera art. 24 k.c., który stwierdza, że ten, czyje dobro osobiste zostało naruszone cudzym działaniem, może żądać od osoby, która się go dopuściła, dopełnienia czynności potrzebnych do usunięcia jego skutków, w tym złożenia oświadczenia odpowiedniej treści i w odpowiedniej formie, którym w praktyce często bywa żądanie złożenia odpowiedniego oświadczenia w przedmiocie przeprosin ${ }^{43}$.

Do aktu przebaczenia odwołują się przepisy prawa cywilnego w zakresie regulacji normatywnej dotyczącej instytucji darowizny oraz uznania za niegodnego i wydziedziczenia w prawie spadkowym. Zgodnie z art. $899 \S 1$ k.c. darowizna nie może być odwołana z powodu niewdzięczności, jeżeli darczyńca obdarowanemu przebaczył ${ }^{44}$. W art. $930 \S 1$ k.c. ustawodawca stwierdził, że spadkobierca nie może być uznany za niegodnego, jeżeli spadkodawca mu przebaczył ${ }^{45}$. Natomiast w art. $1010 \S 1$ k.c. czytamy, że spadkodawca nie może wydziedziczyć uprawnionego do zachowku, jeżeli mu przebaczył ${ }^{46}$. Ponadto na uwagę zasługuje dorobek doktryny i orzecznictwa w zakresie problematyki wpływu przebaczenia na ustalenie winy za rozkład pożycia małżeńskiego w sprawach rozwodowych ${ }^{47}$.

Kwestia pojednania podejmowana jest wprost w regulacjach prawa karnego dotyczących orzekania nawiązki oraz zastosowania nadzwyczajnego złagodzenia kary. W art. 47 § 4 k.k. ustawodawca przewidział, że w szczególnie uzasadnionych okolicznościach, gdy wymierzona nawiązka powodowałaby dla sprawcy uszczerbek dla niezbędnego utrzymania siebie i rodziny lub gdy pokrzywdzony pojednał się ze sprawca, sąd może ją wymierzyć w wysokości niższej niż wskazana w $\S 3$. Natomiast art. $60 \S 2$ pkt 1 k.k. przewiduje, że sąd może zastosować nadzwyczajne złagodzenie kary w szczególnie uzasadnionych wypadkach, kiedy nawet najniższa kara przewidziana za przestępstwo byłaby niewspółmiernie surowa, w szczególności jeżeli pokrzywdzony pojednał się ze sprawcą ${ }^{48}$.

Analizujac instytucje przeprosin, przebaczenia i pojednania w prawie karnym, nie można pominać art. 53 k.k., w którym wskazano, że sąd, wymierzając karę, uwzględnia między innymi zachowanie się sprawcy po popełnieniu przestępstwa, a zwłaszcza staranie o naprawienie szkody lub zadośćuczynienie w innej formie społecznemu poczuciu sprawiedliwości, a także zachowanie się pokrzywdzonego. Sąd ponadto bierze pod uwagę pozytywne wyniki przeprowadzonej mediacji pomiędzy pokrzywdzonym a sprawcą albo ugodę pomiędzy nimi osiagniętą w postępowaniu przed sądem lub prokuratorem ${ }^{49}$. Zarówno akt przeprosin, przebaczenia, jak i pojednania moga stanowić istotny element zachowania się sprawcy i pokrzywdzonego, zwłaszcza w wyniku przeprowadzonego postępowania mediacyjnego zakończonego zawarciem ugody.

\footnotetext{
${ }^{42}$ Zob. ustawa z 6 czerwca 1997 r. - Kodeks karny, t. jedn.: Dz. U. 2018, poz. 1600 ze zm.

43 Zob. ustawa z 24 kwietnia 1964 r. - Kodeks cywilny, t. jedn.: Dz. U. 2019, poz. 1145.

44 Szerzej np. Krajewski (1997): 65-97.

45 Krajewski (1997): 65-97.

${ }^{46}$ Krajewski (1997): 65-97.

47 Zob. np. Domański (2017): 19-20, 49-50.

48 Domański (2017): 19-20, 49-50. Szerzej np. Misztal-Konecka (2013): 65-78.

49 Domański (2017): 19-20, 49-50.
} 
W tym miejscu warto podkreślić, że mając na uwadze wieloaspektowe cele mediacji w różnych typach sporów cywilnych czy karnych, które zwłaszcza ramach w tzw. mediacji transformatywnej nie koncentrują się wyłącznie na zawarciu porozumienia uwzględniającego interesy i potrzeby obydwu stron, ale przede wszystkim na poprawie ich komunikacji, relacji oraz pozytywnej przemianie behawioralnej i personalnej - doprowadzenie do spełnienia aktu przeprosin, przebaczenia czy pojednania może odegrać kluczową rolę w realizacji tych celów oraz ograniczeniu albo likwidacji nie tylko negatywnych skutków konfliktu, lecz także ich przyczyn ${ }^{50}$.

Analiza polskich regulacji materialnego prawa cywilnego i karnego, które odwołują się wprost do przeprosin, przebaczenia lub pojednania, pozwala na stwierdzenie, że dotyczą one jedynie nielicznych instytucji. Niemniej moga one być szeroko wykorzystywane podczas różnorodnych form opanowywaniu sporów prawnych. W szczególności zasługują one na zainteresowanie prawników, którzy przyjmują rolę peacemakera, świadcząc pomoc klientom/ stronom sporów w ramach postępowań negocjacyjnych lub mediacyjnych. W zależności od potrzeb i możliwości danej sprawy moga być one również odpowiednio uwzględniane w praktyce doradczej oraz w arbitrażowym i sądowym rozstrzyganiu sporów. W tym miejscu należy zwrócić uwagę na najnowszą nowelizację Kodeksu postępowania cywilnego, wprowadzająca od 7 listopada 2019 r. instytucję posiedzenia przygotowawczego, prowadzonego przez sędziego z udziałem stron procesu cywilnego lub ich pełnomocników ${ }^{51}$. Zgodnie z art. 205(5) $§ 1$ oraz art. 205(6) § 2 k.p.c. posiedzenie przygotowawcze służy rozwiązaniu sporu bez potrzeby prowadzenia dalszych posiedzeń (zwłaszcza rozprawy), podczas jego przebiegu przewodniczący powinien skłaniać strony do pojednania oraz dążyć do ugodowego rozwiązania sporu, w szczególności w drodze mediacji ${ }^{52}$. Przedmiotowa instytucja procesowa może przyczynić się zatem do zwiększenia praktyki peacemaking w zakresie opanowywania sporów prawnych nie tylko po stronie prawników, pełniących rolę pełnomocników procesowych, ale również sędziów.

\section{PODSUMOWANIE}

Możliwości sprawczych prawników nie można przeceniać, wydaje się jednak, że wciąż mamy do czynienia ze zbyt niskim wykorzystaniem potencjału profesji prawniczych w zakresie polubownego opanowywania konfliktów oraz w budowaniu pokojowego współistnienia społecznego ${ }^{53}$. Stąd zasadne jest po-

50 Szerzej na temat wieloaspektowych celów mediacji w wymiarze personalnym, interpersonalnym, społecznym, psychologicznym, komunikacyjnym oraz negocjacyjno-informacyjnym - zob. Zienkiewicz (2007): 96-123. Na temat założeń mediacji transformatywnej - zob. np. Bush, Folger (2005).

51 Zob. ustawa z 4 lipca 2019 r. - o zmianie ustawy Kodeks postępowania cywilnego oraz niektórych innych ustaw: Dz. U. 2019, poz. 1469.

52 Zob. ustawa z 17 listopada 1964 r. - Kodeks postępowania cywilnego, t. jedn.: Dz. U. 2019, poz. 1460 ze zm.

53 Zienkiewicz (2018): 13. 
pularyzowanie wśród prawników wiedzy na temat istoty i zalet postawy określanej mianem lawyer as peacemaker oraz odpowiednie zachęcanie ich do tego, aby poważnie rozważyli prowadzenie własnej praktyki zawodowej, opierając się na tzw. peacemaking (zwłaszcza podczas opanowywania sporów poprzez mediację czy negocjacje integracyjne, w tym prowadzone w ramach tzw. collaborative law). Instytucje przeprosin, przebaczenia oraz pojednania nie powinny być traktowane przez prawników pejoratywnie, jako zawsze ujawniające słabość, skłonność do podporządkowywania się, nieracjonalnego przyznawania się do winy czy uznawania racji drugiej strony sporu. Nie zasługują one również na marginalizowanie ze względu na brak w danym systemie prawa licznych regulacji prawa cywilnego czy karnego wprost do nich się odwołujacych. Odpowiednie docenianie przez prawników instytucji przeprosin, przebaczenia oraz pojednania jest bowiem szczególnie istotne w codziennej praktyce opanowywania różnorodnych sporów prawnych w sprawach cywilnych, rodzinnych, sasiedzkich, gospodarczych, karnych czy z zakresu prawa pracy, gdyż daje stronom szanse na wzajemne zrozumienie, zlikwidowanie nie tylko negatywnych skutków konfliktu, ale również ich przyczyn, a także na bardziej satysfakcjonujące i harmonijne funkcjonowanie indywidualne i społecz$n \mathrm{e}^{54}$. Najwyższy czas, aby przestały one być traktowane jako domena pomocy świadczonej wyłącznie przez psychologów, terapeutów czy osoby duchowne.

Prawnicy, którzy w swojej praktyce zawodowej kierują się chęcią realnej i trwałej pomocy reprezentowanych przez siebie stronom, nie mogą być ignorantami w zakresie umiejętnego aplikowania i wykorzystania zalet instytucji przeprosin, przebaczenia i pojednania podczas opanowywania sporów. Wiedza i umiejętności w tym zakresie powinny być doskonalone już podczas edukacji na studiach i aplikacjach prawniczych. Jak trafnie wskazał Warren Burger (były prezes Sądu Najwyższego Stanów Zjednoczonych), prawnicy w szerokim rozumieniu tejże profesji winni być prawnymi architektami, inżynierami, budowniczymi i od czasu do czasu wynalazcami, skoncentrowanymi na pomocy w osiaganiu zgody i stabilizacji stosunków społecznych dla dobra demokracji, która najlepiej funkcjonuje, gdy opiera się na kompromisie. Prawnicy powinni być promotorami postępu społecznego, konstruktorami fundamentów, umożliwiających nie tylko odpowiednie rozwiązywanie problemów i sporów, lecz także transformację i ewolucję prawa, i pełnić rolę podmiotów pomagających $\mathrm{w}$ budowaniu harmonii, pokoju społecznego oraz uzdrawianiu relacji interpersonalnych, a nie inicjujących czy eskalujących konflikty ${ }^{55}$.

\section{Adam Zienkiewicz}

Uniwersytet Warmińsko-Mazurski w Olsztynie

adam.zienkiewicz@uwm.edu.pl

https://orcid.org/0000-0002-2824-7123

${ }^{54}$ Por. Daicoff (2013):131-180. Zob. również rozważania na temat funkcjonowania prawnika w kontekście etycznym, w ramach holistycznego podejścia do praktyki prawniczej (w tym podczas realizowania roli peacemakera), bazujacego na specyficznie rozumianej postawie think like professional, wykraczajaccej poza tradycyjny paradygmat think like a lawyer - Zienkiewicz (2018): 194-203. Por. Perry (2008): 159-165; Schiltz (1999): 871-951.

55 Burger (1980): 378; Zienkiewicz (2018): 412-413. 
Augustyn, J. (2011). Kazanie na Górze. Rozważania rekolekcyjne oparte na „Ćwiczeniach duchownych" św. Ignacego Loyoli. Synteza. Kraków.

Baruch Bush, R., Folger, J. (2005). The Promise of Mediation. The Transformative Approach to Conflict. New and Revision Edition. San Francisco.

Berman, G., Feinblatt, J. (2002). Judges and Problem-Solving Courts. New York.

Bieliński, A. (2013). Prawnik i jego misja w ramach procedur alternatywnego rozwiazywania sporów w warunkach kryzysu klasycznego wymiaru sprawiedliwości. Kwartalnik ADR. Arbitraż i Mediacja 2(22): 25-34.

Burger, W.E. (1980). The role of the law school in the teaching of legal ethics and professional responsibility. Cleveland State Law Review 29: 377-395.

Carter, C. (ed.) (2010). Conflict Resolution and Peace Education: Transformations across Disciplines. New York.

Ciszewski, J. (2014). Komentarz do art. 930 Kodeksu cywilnego [stan prawny: 1.05.2014]. System Informacji Prawnej Lex (Lex Omega), [dostęp: 6.09.2019].

Cohen, J. (1999). Advising clients to apologize. Southern California Law Review 72: 1009-1069.

Daicoff, S. (2011). Comprehensive Law Practice, Law as a Healing Profession. Durham.

Daicoff, S. (2013). Apology, forgiveness, reconciliation, \& therapeutic jurisprudence. Pepperdine Dispute Resolution Law Journal 13: 131-180.

Domański, M. (2017). Orzekanie o winie rozkładu pożycia w wyroku rozwodowym. Raport z badania pilotażowego. Warszawa: Instytut Wymiaru Sprawiedliwości, <https://iws.gov.pl/wp-content/uploads/2018/08/IWS-Doma\%C5\%84ski-M.-Orzekanie-o-winie-rozk\%C5\%82adu-po\%C5\%BCycia-w-wyroku-rozwodowym.pdf> [dostęp: 16.09.2019].

Gutterman, S. (2004). Collaborative Law: A New Model of Dispute Resolution. Denver.

Kaczmarek, P. (2014). Tożsamość prawnika jako wykonawcy roli zawodowej. Warszawa.

Karaszewski, G. (2014). Komentarz do art. 899 Kodeksu cywilnego [stan prawny: 1.05.2014]. System Informacji Prawnej Lex (Lex Omega), [dostęp: 6.09.2019].

King, M., Freiberg, A., Batagol, B., Hymas, R. (2009). Non-Adversarial Justice. Sydney.

Kołakowski, L. (2007). Miniwykłady o maxisprawach. Trzy serie. Kraków.

Korybski, A. (1993). Alternatywne rozwiązywanie sporów w USA - studium teoretycznoprawne. Lublin.

Krajewski, M. (1997). Przebaczenie i inne okoliczności wyłączające możliwość uznania spadkobiercy za niegodnego. Państwo i Prawo 52(5): 65-74.

Księżak, P. (2006). Przebaczenie w polskim prawie cywilnym. Państwo i Prawo 61(11): 54-66.

Lazare, A. (2005). On Apology. New York.

Łojko, E. (2005). Role i zadania prawników w zmieniającym się społeczeństwie. Warszawa.

Maliszewski, K. (2016). Szaleństwo niemożliwego versus przepracowanie - przebaczenie jako paradoksalny mechanizm rozwojowy. Paedagogia Christiana 38(2): 11-24.

Martini, C.M. (2008). Kazanie na Górze. Medytacje biblijne. Kielce.

Misztal-Konecka, J. (2013). Pojednanie w prawie polskim (zagadnienia wybrane). Prokuratura i Prawo 12: 65-78.

Mularski, K. (2011). Czynności podobne do czynności prawnych. Warszawa.

Noll, D. [b.d.]. What is Peacemaking? <http://www.mediate.com/articles/noll4.cfm> [dostęp: 9.09.2019].

Ochotny, P. (2017). Nie mówię ci, że aż 7 razy, lecz aż 77 razy (Mt 18, 22). Czy przebaczenie można nakazać? Przebaczenie aktem sprawiedliwości czy miłości? Warszawskie Studia Pastoralne UKSW 2(35): 87-101.

Perry, J. (2008). Thinking like a professional. Journal of Legal Education 58(2): 159-165.

Płeszka, K., Czapska, J., Araszkiewicz, M., Pękala, M. (2017). Mediacja. Teoria, normy, praktyka. Warszawa.

Rękas, A. (2011). Mediacja w Polsce w prawie karnym. Warszawa.

Saint-Cheron, M. (2008). Rozmowy z Emmanuelem Lévinasem. Warszawa.

Scheff, T. (1998). Community conferences: shame and anger in therapeutic jurisprudence. Revista Juridica U.P.R. 67: 104-106.

Schiltz, P. (1999). On being a happy, healthy, and ethical member of an unhappy, unhealthy, and unethical profession. Vanderbilt Law Review 52(4): 871-951.

Skapska, G., Czapska, J., Kozłowska, M. (1989). Społeczne role prawników (sędziów, prokuratorów, adwokatów). Wrocław-Warszawa-Kraków-Łódź. 
Skowrońska-Bocian, E. (2017a). Komentarz do art. 930 Kodeksu cywilnego [stan prawny: 1.03.2017]. System Informacji Prawnej Lex (Lex Omega), [dostęp: 6.09.2019].

Skowrońska-Bocian, E. (2017b). Komentarz do art. 1010 Kodeksu cywilnego [stan prawny: 1.03.2017]. System Informacji Prawnej Lex (Lex Omega), [dostęp: 6.09.2019].

Stecki, L. (2011). Prawo zobowiązań - część szczegółowa, [w:] J. Rajski (red.), System prawa prywatnego. Tom 7. Warszawa: 356-357.

Tesler, P. (2008). Collaborative Law. Achieving Effective Resolution in Divorce without Litigation. 2nd edn. Chicago.

Trzaskowski, R. Komentarz do art. 899 Kodeksu cywilnego [stan prawny: 1.03.2017]. System Informacji Prawnej Lex (Lex Omega), [dostęp: 06.09.2019].

Wiener, R., Brank, E. (eds.) (2013). Problem Solving Courts. Social Science and Legal Perspectives. New York-Heidelberg-Dordrecht-London.

Wilejczyk, M. (2013). Cywilnoprawne znaczenie przebaczenia. Studia Prawnicze 1: 101-111.

Wilejczyk, M. (2018). Krzywda, przebaczenie i zadośćuczynienie. Perspektywa prawna i etyczna. Ethos 2(122): 273-289.

Winick, B., Wexler, D. (eds.) (2003). Judging in a Therapeutic Key: Therapeutic Jurisprudence and the Courts. Durham.

Winnick, B. (2003). Therapeutic jurisprudence and problem solving courts. Fordham Urban Law Review 30: 1055-1090.

Winick, B. (2013). Problem solving courts: therapeutic jurisprudence in practice, [w:] R. Wiener, E. Brank (eds.), Problem Solving Courts. Social Science and Legal Perspectives. New YorkHeidelberg-Dordrecht-London.

Wright, J.K. (2010). Lawyers as Peacemakers. Practicing Holistic, Problem Solving Law. Chicago. Zienkiewicz, A. (2007). Studium mediacji od teorii ku praktyce. Warszawa.

Zienkiewicz, A. (2014). Specyfika dyskursu integracyjnego, [w:] J. Bralczyk, J. Dubois, G. Holoubek, C. Jaworski, Z. Krzemiński, G. Matyszkiewicz, J. Naumann, K. Piesiewicz, M. Radwan-Rohrenschef, A. Rościszewski, J. Stuhr, A. Tomaszek, J. Wasilewski, E. Wende, T. de Virion, Z. Zapasiewicz, J. Zajadło, K. Zeidler, A. Zienkiewicz, Wymowa prawnicza. Wydanie 4. Warszawa: 189-198.

Zienkiewicz, A. (2018). Holizm prawniczy z perspektywy Comprehensive Law Movement. Studium teoretycznoprawne. Warszawa.

\section{LAWYER AS PEACEMAKER \\ - APOLOGY, FORGIVENESS, RECONCILIATION IN DISPUTE RESOLUTION}

\section{Summary}

The constant search, research and application of various, amicable forms of dispute resolution, including those using institutions such as apology, forgiveness and reconciliation, should be considered as justified, as it can bring benefits in the individual, interpersonal and social spheres. The aim of the article is to present the specific professional or social role that lawyers can perform, especially during dispute resolution, known as lawyer as peacemaker. This paper describes the understanding of the lawyer's specific role as a peacemaker, based on the author's concept of a holistic approach to law and legal practice. The paper analyses the essence of the institution of apology, forgiveness and reconciliation, which are particularly significant for the practice of alternative dispute resolution, based on peacemaking. Finally, selected Polish civil and criminal law regulations referring to apology, forgiveness or reconciliation are identified.

Keywords: lawyer; peacemaker; apology; forgiveness; reconciliation; Alternative Dispute Resolution; holistic approach to law and legal practice 
